\title{
Genomic aberrations in normal appearing mucosa fields distal from oral potentially malignant lesions
}

\author{
W. Giaretti • M. Maffei • M. Pentenero • P. Scaruffi • A. Donadini • E. Di Nallo • \\ D. Malacarne • R. Marino • U. Familiari • S. Coco • G. P. Tonini • P. Castagnola • \\ S. Gandolfo
}

Accepted: 17 November 2011 /Published online: 6 December 2011

(C) The Author(s) 2011. This article is published with open access at Springerlink.com

\begin{abstract}
Objectives Oral fields of visually normal and nondysplastic mucosa (ODFs) may represent the precursors of oral potentially malignant lesions (OPMLs). Aim of the study was to provide new evidence for the concept of the "field carcinogenesis" model by comparing the ODF and OPML genomic aberration profiles obtained by high resolution DNA flow cytometry (hr DNA-FCM) and array-Comparative Genomic Hybridization (a-CGH). A second aim was to investigate if specific CGH aberrations were associated with DNA aneuploidy.
\end{abstract}

\footnotetext{
W. Giaretti $(\bowtie) \cdot$ M. Maffei $\cdot$ A. Donadini $\cdot$ E. Di Nallo

D. Malacarne $\cdot$ P. Castagnola

Department of Diagnostic Oncology, Biophysics and Cytometry,

National Institute for Cancer Research,

Largo Rosanna Benzi n.10,

16132, Genoa, GE, Italy

e-mail: walter.giaretti@istge.it

M. Pentenero $\cdot$ R. Marino $\cdot$ S. Gandolfo

Department of Clinical and Biological Sciences,

Oral Medicine and Oral Oncology Section, University of Turin,

Turin, Italy

P. Scaruffi $\cdot$ S. Coco $\cdot$ G. P. Tonini

Department of Diagnostic Oncology, Translational

Oncopathology Section, National Institute for Cancer Research,

Genoa, Italy

U. Familiari

Pathology Division, AOU S. Luigi Gonzaga,

Orbassano, Italy

Present Address:

P. Scaruffi

Center of Physiopathology of Human Reproduction, Department

of Obstetrics and Gynecology, "San Martino" Hospital,

Genoa, Italy
}

Methods Nineteen patients with single OPMLs were recruited for the study. In parallel with obtaining samples of OPML tissue from 11 leukoplakias without dysplasia (nd-OPMLs) and 8 with dysplasia (d-OPMLs), we also obtained samples from distant ODFs. DNA aneuploid nuclei detected by hr DNA-FCM were physically separated, based on DNA content, from the DNA diploid components with a DNA-FCM-Sorter. These relatively pure subpopulations of epithelial nuclei were then submitted to DNA extraction and a-CGH for a genome-wide analysis of DNA copy number aberrations (CNAs).

Results The frequencies of DNA aneuploidy $(\mathrm{DI} \neq 1)$ among ODFs and OPMLs were respectively $5.3 \%$ and $32 \%$. The DI aneuploid values of ODFs and nd-OPMLs were all neardiploid ( $\mathrm{DI} \neq 1$ and $\mathrm{DI} \leq 1.4$ ), while for $\mathrm{d}$-OPMLs were highaneuploid (DI $>1.4)$ in $40 \%$ of the cases. CNA averages were 1.9 in ODFs and 6.5 in OPMLs. The gain of the chromosomal region $20 \mathrm{q} 13.33$-qter was observed in $37 \%$ of both ODFs and corresponding OPMLs. Additional common regions included 7p22.2-pter, $11 \mathrm{p} 15.5$-pter and 16p13.3-pter where gains were observed. Furthermore, gains of 20q13.31-q13.33 and of 5p13.33-pter and loss of $9 \mathrm{p} 21.3$ were detected at high frequency (respectively, at $62.5 \%, 50 \%$ and $50 \%$ ) only in d-OPMLs. In particular, loss at $9 \mathrm{p} 21.3$, gain at $5 \mathrm{p} 13.33$-pter and gain of 20q13.31q13.33 were associated with DNA aneuploidy ( $p=0.00004$; $p=0.0005 ; p=0.01$ ).

Conclusions ODFs and OPMLs showed common CNAs in specific chromosomal regions suggesting that they may represent early events of the natural history of oral carcinogenesis according to the field effect cancerization and may contribute to the ODF-OPML transition. In addition, loss at 9p21.3 and gains at 5p13.33-pter and 20q13.31-q13.33 may contribute to DNA aneuploidization. 
Keyword Controlateral distant fields · Oral potentially malignant lesions · Field effect cancerization · DNA aneuploidy Copy number aberrations · Flow cytometry . Comparative genomic hybridization

\section{Introduction}

Accumulation of genetic/genomic aberrations are thought to lead to a multi-step process of cancer genesisprogression, in which the functions of genes controlling the cell cycle, cell death, chromosomal stability, angiogenesis, invasion and metastasis become aberrant [1-3]. Epidemiologic and experimental evidences indicate that most oral cancers originate and progress with the contribution of carcinogen exposure, mainly from tobacco smoking $[4,5]$. Recently, using parallel sequencing technology and a lung cell line, a total of 22.910 somatic substitutions were identified, including 134 in coding exons [6]. More than 60 chemicals derived from tobacco smoking that bind and mutate DNA within the oral mucosa cells may contribute, in particular, to create an extensive "field cancerization" [79]. Specific gene mutations are also thought to contribute to inhibit DNA repair and to increase DNA damage within the entire mucosa and, in particular, to generate chromosomal instability and aneuploidy resulting in an increased risk of developing oral cancer. The theory of "field cancerization" [7] and its more recent genetic explanation [8, 9] have generated a very attractive genetic progression model of oral cancer [10]. A critical step in this model, however, is the conversion of a patch, in which stem cells share genetic/ genomic aberrations, into an expanding field with numerous aberrations, which sometimes becomes visible as leukoplakias [11-15]. Along the concepts of this model, many studies have compared several types of DNA aberrations within samples from oral cancer (mainly, oral squamous cell carcinomas, OSCCs) and of oral tissue in the vicinity of OSCCs. These studies include investigations on loss of heterozygosity [9, 16, 17] and detection of molecular and cellular aberrations by in situ hybridization [18, 19], immunohistochemistry [18, 19], multiplex ligation-dependent probe amplification [17], DNA image [17] and flow cytometry [20].

Oral cancer was also characterized by different chromosomal aberrations located in specific chromosomal loci including 1p36.3, 3q26, 7p, 8q, 9p, 11q13, 16p, 16q, 17q, 20q [21-27]. Recently, we have investigated the presence of DNA aneuploid sublines by hr DNA-FCM within ODFs, OPMLs and OSCCs, suggesting a model of DNA aneuploidization $[20,28]$. In the present study, we aimed to investigate visually normal appearing and histologically non-dysplatic mucosa fields (ODFs) distant with respect to non-dysplastic and dysplastic OPMLs (nd- and d-OPMLs).
Our experimental approach was based on hr DNA-FCM to detect DNA aneuploid sublines. DNA near-diploid aneuploid sublines with a DI difference between 2 and $4 \%$ with respect to DNA diploid control cells could be detected [20]. A DNA-FCM-Sorter was then used to physically separate the epithelial DNA aneuploid sublines in order to extract specific DNA to submit to a genomewide a-CGH analysis providing DNA copy number aberrations (CNAs). These combined techniques may potentially provide new evidence for the conversion of a patch (represented by the ODFs) into an expanding field, which became visible as leukoplakias (nd-OPMLs and d-OPMLs). The first aim was to address whether the ODFs and the OPMLs shared specific chromosomal changes. The second aim was to compare chromosomal aberrations with DNA aneuploidy to eventually identify genomic regions underlying the development of DNA aneuploid sublines.

\section{Materials and methods}

\subsection{Patients and histological assessment}

Patients with OPMLs were recruited in two different medical centers: the Oral Medicine and Oral Oncology Section of the University of Turin at the A.O.U. S. Luigi Gonzaga (Orbassano-Turin) and at the Department of Otolaryngology, "S. Martino Hospital" in Genoa. Patient written consent was obtained in every case according to the Institutional Ethic Committees (A.S.O. S. Luigi Gonzaga Prot. N. 11780 and S. Martino Hospital Prot. N. 1084) during an interview in which their tobacco and alcohol habits were recorded.

Nineteen patients ( 9 males and 10 females, with a mean age of 57.9 years, range $32-76$ years) with nd- and dOPMLs, gave their informed consent and were included in this study. The patients were also interviewed as to their tobacco habit and the results were recorded: 8 patients were non-smokers (NS) and 11 were smokers (S). Tissue samples were obtained from both the OPMLs and from distal corresponding ODFs in 18 out of 19 patients. The only exception was the ODF of the patient 16 , which allowed the sampling of healthy tissue only from the buccal mucosa and not from the tongue, which was the subsite affected by the OPML. Sampling was performed by means of incisional biopsy and/or micro-biopsy as previously detailed [29], taking care to cause slight bleeding to ensure that the basal layers of the epithelium had been collected. Part of the sample was formalin-fixed to assess the presence of dysplasia by means of routine haematoxylin and eosin stained slides. Additional multiple samples were immediately frozen and stored at $-20^{\circ} \mathrm{C}$ for later measurements by hr DNA-FCM and a-CGH. The diagnosis of OPMLs (all 
leukoplakias) was based on internationally accepted criteria with levels of diagnostic certainty $\mathrm{C} 3-\mathrm{C} 4$ [30], while the histological diagnosis for the assessment of the presence of dysplasia was carried out by a specially trained pathologist, according to the WHO guidelines [31]. The anatomical subsites, which were in common in 18 out of 19 cases for both ODFs/OPMLs, were for the vast majority of the cases buccal mucosa. ODFs were not always equally distant from the corresponding OPML lesions. In some cases, as for example, when the OPMLs were on a cheek, the ODF samples were obtained from the opposite cheek. This was an optimal situation, which identifies the ODF position as "controlateral" or "mirror" with respect to the OPML position. On the contrary, when the lesion was on the anterior floor of the mouth, ODFs could be too close to the lesion. Therefore, OPMLs close to the midline were not included in the present study. The anatomical subsites of the ODFs/OPMLs are reported in Table 1.

\subsection{Flow cytometric analysis and sorting}

Multiple tissue samples were processed to obtain DAPI stained nuclei suspensions following the method of Otto et al. [32] with modifications. Hr DNA-FCM of these samples was done as previously described in details using a CyflowML cytometer (Partec GmbH, Muenster, Germany) to obtain DNA content histograms and to evaluate the DNA Index (DI) [33]. DNA diploid controls were represented by gender-specific human lymphocytes. The mean CV of the corresponding DNA diploid G0-G1 peaks was $1.2 \pm 0.2 \%$. DNA near-diploid aneuploid sublines with a DI difference between 2 and $4 \%$ with respect to DNA diploid control cells could be detected [20].The DNA aneuploid sublines $(\mathrm{DI} \neq 1)$ were sorted using a Cyflow Space FCM equipped with a PPCS unit (Partec $\mathrm{GmbH})$ at the purity of about $99 \%$.

\subsection{DNA extraction}

DNA extraction was performed using ArchivePure DNA kit (5-Prime, Hamburg, Germany) with some modifications: after proteins precipitation the DNA was purified by phenol-chloroform extraction and collected by ethanol precipitation using $20 \mu \mathrm{g}$ of glycogen $(20 \mathrm{mg} / \mathrm{ml})$ as carrier. DNA quality was assessed by agarose gel and ND-1000 Spectrophotometer (NanoDrop Technologies, Wilmington, DE).

\subsection{Analysis by a-CGH}

The a-CGH analysis was carried out using oligonucleotide Human Genome CGH $105 \mathrm{~K}$ array platform (Agilent Technologies, Santa Clara, CA). A pool of normal male or female DNA (Promega, Madison, WI) was used as reference DNA. Briefly, $50 \mathrm{ng}$ of genomic DNA were amplified by GenomePlex Whole Genome Amplification Kit WGA2 (Sigma-Aldrich, St. Louis, MO). When the total amount of DNA was lower than $50 \mathrm{ng}$ the amplification was performed by Ovation WGA System (NuGEN, San Carlos, CA, USA). For each array, amplified test and reference DNAs $(2 \mu \mathrm{g}$ each) were labeled by Bioprime Labelling Kit (Invitrogen, Paisley, UK). Slides were hybridized and washed according to manufacture's recommendations. Spot fluorescence was measured by the Agilent G2565BA Scanner and images were processed by Feature Extraction software (version 9.5.3.1) (Agilent Technologies). Data files were analyzed by Agilent CGH Analytics Software (version 3.5.14) according to ADM-2 algorithm. The quality of each experiment was assessed by QC metric tool. Oligonucleotides were mapped according to the human genome build NCBI35/Hg17 (May 2004). Raw data were uploaded in Gene Expression Omnibus: (http://www.ncbi.nlm.nih.gov/projects/geo/ index.cgi, accession number: GSE28906). We have used commercially available pooled normal DNA from healthy donors. We excluded those copy number variations (CNVs) that were listed as large segment copy number polymorphisms by Genomic Variants Database (http:// projects.tcag.ca/variation).

Several tests were also performed to exclude that a-CGH results could be affected by WGA, DAPI staining and the DNA-FCM-Sorting (data not shown).

\subsection{Statistical analysis}

Data collection, management and analyses were done using Microsoft Office Excel and the SPSS 16.0 software package (Apache Software Foundation, Chicago, IL). The association among variables in contingency tables was evaluated with the Fisher exact test (two-sided) or the chisquared test. A $p$-value $\leq 0.05$ was taken as statistically significant.

\section{Results}

Table 1 shows the main characteristics of the patients (gender, age and tobacco smoking habit), the subsites, the histology of the ODFs and OPMLs and the corresponding DI values by DNA-FCM and CNAs by a-CGH. On the basis of the histological diagnosis, the group of OPMLs in the present series included 11 leukoplakias without dysplasia (nd-OPMLs) and 8 dysplastic leukoplakias (d-OPMLs). Dysplasia was never detected in the corresponding 19 ODFs. The frequencies of DNA aneuploidy in ODFs and 
Table 1 Patient's and sample characteristics with DI values by hr DNA-FCM and CNAs by a-CGH for 19 ODFs and 19 OPMLs

\begin{tabular}{|c|c|c|c|c|c|c|c|c|}
\hline $\mathrm{Pt}$ & Gender & Age & $\begin{array}{l}\text { Smoke } \\
\text { habit }\end{array}$ & Site & Sample & DI & CNAs-Gains & CNAs-Losses \\
\hline \multirow[t]{2}{*}{1} & $\mathrm{~F}$ & 56 & $\mathrm{~S}$ & $\mathrm{BM}(\mathrm{c})$ & ODF & 1 & None & None \\
\hline & & & & $\mathrm{BM}(\mathrm{c})$ & nd-OPML & 1 & None & None \\
\hline \multirow[t]{2}{*}{2} & $\mathrm{~F}$ & 39 & $\mathrm{~S}$ & $\mathrm{BM}(\mathrm{c})$ & ODF & 1 & None & None \\
\hline & & & & $\mathrm{BM}(\mathrm{c})$ & nd-OPML & 1 & None & None \\
\hline \multirow[t]{2}{*}{3} & $\mathrm{~F}$ & 55 & $\mathrm{~S}$ & $\mathrm{BM}(\mathrm{c})$ & ODF & 1 & None & None \\
\hline & & & & $\mathrm{BM}(\mathrm{c})$ & nd-OPML & 1 & None & None \\
\hline \multirow[t]{2}{*}{4} & M & 70 & NS & $\mathrm{BM}(\mathrm{c})$ & ODF & 1 & None & None \\
\hline & & & & $\mathrm{BM}(\mathrm{c})$ & nd-OPML & 1 & $2 \mathrm{p} 12$ & None \\
\hline \multirow[t]{2}{*}{5} & $\mathrm{~F}$ & 68 & $\mathrm{~S}$ & $\mathrm{BM}(\mathrm{c})$ & ODF & 1 & $\begin{array}{l}\text { 11p15.5-pter; } 16 \text { p13.3-pter; } \\
\text { 20q13.33-qter }\end{array}$ & None \\
\hline & & & & $\mathrm{BM}(\mathrm{c})$ & nd-OPML & 1 & None & None \\
\hline \multirow[t]{2}{*}{6} & M & 58 & NS & $\mathrm{BM}(\mathrm{c})$ & ODF & 1 & None & None \\
\hline & & & & $\mathrm{BM}(\mathrm{c})$ & nd-OPML & 1 & None & $\begin{array}{l}\text { 5p15.33-pter; 7p22.3-pter; } \\
\text { 8q24.3-qter; 10q26.3-qter; } \\
\text { 11p15.5-pter; 12q24.33-qter; } \\
\text { 16p13.3-pter; 20q13.3-qter; } \\
\text { 21q22.3-qter }\end{array}$ \\
\hline \multirow[t]{2}{*}{7} & $\mathrm{~F}$ & 40 & NS & $\mathrm{BM}(\mathrm{c})$ & ODF & 1 & None & None \\
\hline & & & & $\mathrm{BM}(\mathrm{c})$ & nd-OPML & 1 & None & None \\
\hline \multirow[t]{2}{*}{8} & $\mathrm{~F}$ & 50 & S & Others (hp) & ODF & 1 & $\begin{array}{l}\text { 7p22.2-pter; 8q24.3-qter; } \\
\text { 10q26.3-qter; 20q13.33-qter }\end{array}$ & None \\
\hline & & & & Others (hp) & nd-OPML & 1 & $\begin{array}{l}\text { 7p22.2-pter; 8q24.3-qter; } \\
\text { 10q26.3-qter; 11p15.4-pter; } \\
\text { 17q25.1-qter; 20q13.33-qter }\end{array}$ & None \\
\hline \multirow[t]{2}{*}{9} & M & 41 & $\mathrm{~S}$ & $\mathrm{BM}(\mathrm{rt})$ & ODF & 1.30 & $\begin{array}{l}\text { 1p36.32-pter; 16p13.3-pter; } \\
\text { 16q24.2-qter; 17q25.2-qter; } \\
\text { 20q13.33-qter }\end{array}$ & None \\
\hline & & & & $\mathrm{BM}(\mathrm{rt})$ & nd-OPML & 1 & None & None \\
\hline \multirow[t]{2}{*}{10} & M & 32 & NS & $\mathrm{BM}(\mathrm{c})$ & ODF & 1 & None & None \\
\hline & & & & $\mathrm{BM}(\mathrm{c})$ & nd-OPML & 1 & None & None \\
\hline \multirow[t]{2}{*}{11} & $\mathrm{~F}$ & 70 & NS & Tongue & ODF & 1 & None & None \\
\hline & & & & Tongue & nd-OPML & 1.14 & $\begin{array}{l}\text { 7p22.2-pter; } 8 ; 12 ; \\
\text { 16p13.3-pter; 16q24.1-qter; } \\
\text { 20q13.31-qter; X }\end{array}$ & $9 \mathrm{p} 21.3$ \\
\hline \multirow[t]{2}{*}{12} & M & 63 & $\mathrm{~S}$ & $\mathrm{BM}(\mathrm{c})$ & ODF & 1 & None & None \\
\hline & & & & $\mathrm{BM}(\mathrm{c})$ & d-OPML & 1 & None & None \\
\hline \multirow[t]{2}{*}{13} & $\mathrm{~F}$ & 67 & NS & $\mathrm{BM}(\mathrm{c})$ & ODF & 1 & $\begin{array}{l}\text { 1p36.32-pter; 7p22.2-pter; } \\
\text { 8q24.3-qter; 9q33.3-qter; } \\
\text { 10q26.3-qter; 11p15.4-pter; } \\
\text { 16p13.3-pter; 16q23.3-qter; } \\
\text { 17q25.1-qter; 20q13.33-qter; } \\
\text { 21q22.3-qter; 22q13.33-qter }\end{array}$ & None \\
\hline & & & & $\mathrm{BM}(\mathrm{c})$ & d-OPML & 1 & $\begin{array}{l}\text { 1p36.32-pter; 4p16.2-pter; } \\
\text { 7p22.2-pter; 8q24.3-qter; } \\
\text { 9q33.3-qter; 10p26.3-pter; } \\
\text { 11p15.4-pter; 14q32.2-qter; } \\
\text { 16p13.3-pter; 16q23.3-qter; } \\
\text { 20q13.31-qter; 21q22.3-qter }\end{array}$ & None \\
\hline \multirow[t]{2}{*}{14} & M & 60 & $\mathrm{~S}$ & $\mathrm{BM}(\mathrm{c})$ & ODF & 1 & $\begin{array}{l}\text { 7p22.2-pter; 8q24.3-qter; } \\
\text { 10p26.3-pter; 11p15.4-pter; } \\
\text { 16p13.3-pter; 20q13.31-qter; } \\
\text { 22q13.33-qter }\end{array}$ & None \\
\hline & & & & $\mathrm{BM}(\mathrm{co})$ & d-OPML & 1 & $\begin{array}{l}\text { 1p36.32-pter; 4p16.1-pter; } \\
\text { 7p22.2-pter; 8q24.3-qter; } \\
\text { 9q33.3-qter; 10q26.3-qter; } \\
\text { 11p15.4-pter; 14q32.2-qter; }\end{array}$ & None \\
\hline
\end{tabular}


Table 1 (continued)

\begin{tabular}{|c|c|c|c|c|c|c|c|c|}
\hline $\mathrm{Pt}$ & Gender & Age & $\begin{array}{l}\text { Smoke } \\
\text { habit }\end{array}$ & Site & Sample & DI & CNAs-Gains & CNAs-Losses \\
\hline & & & & & & & $\begin{array}{l}\text { 16p13.3-pter; 16q24.1-qter; } \\
\text { 17q25.1-qter; 19p13.1-pter; } \\
\text { 20q13.31-qter; 21q22.3-qter; } \\
\text { 22q13.32-qter }\end{array}$ & \\
\hline \multirow[t]{2}{*}{15} & $\mathrm{~F}$ & 76 & NS & Others $(\mathrm{g})$ & ODF & 1 & None & None \\
\hline & & & & Others $(\mathrm{g})$ & d-OPML & 1.04 & 2 & None \\
\hline \multirow[t]{2}{*}{16} & M & 59 & $\mathrm{~S}$ & $\mathrm{BM}(\mathrm{c})$ & ODF & 1 & None & None \\
\hline & & & & Tongue & d-OPML & 1.04 & $5 \mathrm{p} ; 22 \mathrm{q} 11.21 ; \mathrm{Yp}$ & $\begin{array}{l}\text { 1p12-p21.1; 9p13.3-pter; } \\
\text { 11q22.3-qter; 12p; } \\
\text { 14q11-q31.3; Yq }\end{array}$ \\
\hline \multirow[t]{2}{*}{17} & M & 62 & S & Others (sp) & ODF & 1 & None & None \\
\hline & & & & Others (sp) & d-OPML & 1.20 & $1 \mathrm{q} ; 2 ; 5 ; 8 ; 9 \mathrm{p} 21.3$-pter; 20 & $\begin{array}{l}\text { 1p36.33-pter; 7p22.3-pter; } \\
\text { 9p21.3; 10q26.3-qter; } \\
\text { 11p15.5-pter;14q32.33-qter; } \\
\text { 16p13.3-pter; 16q24.3-qter; } \\
\text { 17q25.1-qter; 19p13,3-pter; } \\
\text { 21q22.3-qter }\end{array}$ \\
\hline \multirow[t]{2}{*}{18} & M & 64 & $\mathrm{~S}$ & Tongue & ODF & 1 & 20q13.33-qter & None \\
\hline & & & & Tongue & d-OPML & 1.67 & $\begin{array}{l}\text { 1q; 2p; 3q13.31-qter; 5p; } 6 \\
7 \mathrm{p} ; 8 \mathrm{q} ; 10 \mathrm{q} ; 11 \mathrm{p} 15.5 \text {-pter; } \\
\text { 11q13.2-q14.1;12p; } \\
\text { 13q12.12;15;16;20; } \\
22 ; X \mathrm{Xp}\end{array}$ & $\begin{array}{l}\text { 2q11-q22.1; 3p12.1-p14.2; } \\
\text { 3q12.1-q13.11; 4q13.1-q14.1; } \\
\text { 5q11-q23.1; 7q21.11-q21.2; } \\
\text { 8p12-pter; 9p21.3-pter; } \\
\text { 9p11-p13.2; 9q; 10p11.21; } \\
\text { 18q21.31-qter; Xq }\end{array}$ \\
\hline \multirow[t]{2}{*}{19} & $\mathrm{~F}$ & 71 & NS & Tongue & ODF & 1 & $\begin{array}{l}\text { 1p36.32-pter; 7p22.2-pter; } \\
\text { 11p15.5-pter; 20q13.33-qter; } \\
\text { 21q22.3-qter }\end{array}$ & None \\
\hline & & & & Tongue & d-OPML & 1.97 & $\begin{array}{l}\text { 1p36.32-pter; 3q13.11-qter; } \\
\text { 5p13.33-pter; 7p22.2-pter; } \\
\text { 8q24.3-qter; 20q13.31-qter }\end{array}$ & $6 ; 9 \mathrm{p} 21.3 ; 13$ \\
\hline
\end{tabular}

Pt patient; DI DNA Index; CNA Copy number aberrations; $N S$ non smoker; $S$ : smoker; OFs: oral fields of visually normal mucosa; $n d-O P M L s$ non-dysplastic oral potentially malignant lesions; $d$-OPMLs dysplastic oral potentially malignant lesions; $B M$ Buccal mucosa; $c$ : cheek; $h p$ hard palate; $r t$ retromolar trigone; co commissure; $g$ gingiva; $s p$ soft palate

OPMLs were $5.3 \%$ and $32 \%$ respectively. The DI aneuploid values among the ODFs and the nd-OPMLs were in all cases near-diploid $(\mathrm{DI} \neq 1$ and $\mathrm{DI} \leq 1.4)$, while in the $\mathrm{d}$ OPMLs were high-aneuploid (DI $>1.4$ ) in $40 \%$ of the cases (Table 1).

Copy number aberrations (CNAs) were observed in 11/ 19 OPMLs (58\%) and in 7/19 ODFs (37\%; Table 2). In 12 out of 19 ODFs (63\%) and in 8/19 OPMLs (42\%) no aberrations were found. In particular, 6 ODFs $(31.6 \%)$ and the corresponding lesions showed a flat profile. ODFs and the corresponding OPMLs had specific CNAs in common in 5 out of 19 cases (29\%). Two ODFs out of 19 (11\%) had, instead, unique CNAs that were absent in the corresponding nd-OPMLs (Table1). The frequency of DNA aneuploidy, which increased from $5.3 \%$ for the ODFs to $32 \%$ for the OPMLs, was paralleled by an increase in the average number of CNAs from 1.9 to 6.47 (Table 2). Moreover, the presence of dysplasia among the OPMLs was associated with an increased average number of CNAs (data not shown).

It is of note that the CNA-gains were more frequent than the CNA-losses among both the ODFs and the OPMLs. In particular, the frequency of CNA-losses among the OPMLs was $32 \%$ versus $0 \%$ among the ODFs $(p=0.02$, Fisher exact test; Table 3). It is also of note that the presence of DNA aneuploidy among all samples was concomitant with an higher number of CNAs, both gains and losses. We also observed that, while segmental chromosomal aberrations (defined as CNAs within a chromosomal segment) were present in both the DNA diploid and aneuploid sublines, numerical chromosomal aberrations (gain/loss of entire chromosomes) were seen only in presence of DNA aneuploidy (Table 1).

Table 4 reports the CNA-gains of 6 minimal common regions with the corresponding segment sizes and number of genes. The most frequent aberrant common region was 
Table 2 DNA ploidy and CNAs among ODFs and OPMLs

\begin{tabular}{|c|c|c|c|c|c|c|c|c|c|c|}
\hline & \multicolumn{4}{|c|}{ DNA ploidy by hr DNA-FCM } & \multicolumn{6}{|c|}{ CNAs by a-CGH } \\
\hline & \multicolumn{2}{|c|}{$\begin{array}{l}\text { DNA diploid } \\
(\mathrm{DI}=1)\end{array}$} & \multicolumn{2}{|c|}{$\begin{array}{l}\text { DNA aneuploid } \\
(\mathrm{DI} \neq 1)\end{array}$} & \multicolumn{2}{|c|}{ absent } & \multicolumn{2}{|c|}{ present } & \multirow[t]{2}{*}{ range } & average \\
\hline ODFs $(n=19)$ & 18 & $(94.7 \%)$ & 1 & $(5.3 \%)$ & 12 & $(63.2 \%)$ & 7 & $(36.8 \%)$ & & 1.9 \\
\hline OPMLs $(n=19)$ & 13 & $(68.4 \%)$ & 6 & $(31.6 \%)$ & 8 & $(42.1 \%)$ & 11 & $(57.9 \%)$ & $1-30$ & 6.47 \\
\hline
\end{tabular}

the gain of $20 q 13.33$-qter, observed in $7 / 19$ cases $(37 \%)$ for both the ODFs and the OPMLs. This aberrant region was more commonly detected in the d-OPMLs (62.5\%) than in the nd-OPMLs $(18 \%)$ (Table1). It is also of note that the frequency of 7p22.2-pter gain was slightly lower in the ODFs $(21 \%)$ that in the OPMLs $(32 \%)$. Similarly, the gain of 8 q24.3-qter was $16 \%$ for the ODFs and $37 \%$ for the OPMLs. A cluster of 3 aberrations, the CNA-gains of the 7p22.2-pter, 8q24.2-qter and 20q13.33-qter regions, was noted simultaneously in $16 \%$ of the ODFs, in $18 \%$ of the nd-OPMLs and in $50 \%$ of the d-OPMLs.

In the present series of 19 OPMLs, 8 were characterized by the presence of dysplasia (d-OPMLs) and of unique types of aberrations, which were absent or at very low frequency in all the other samples. Table 5 reports these aberrations, their start-end positions, segment sizes and the corresponding number of genes: CNA-gains in 5p13.33-pter, 16q24.2-qter and 20q13.31-q13.33 and a CNA-loss in 9p21.3. The corresponding frequencies among d-OPMLs were respectively 50\%, 37.5\%, 62.5\% and $50 \%$.

In the present series of 19 ODFs and 19 OPMLs, 10 different aberrant chromosomal regions have been detected. Table 6 presents the $2 \times 2$ contingency table tests of association between these aberrant chromosomal regions (CNAs with 9 gains and 1 loss) and the DNA ploidy status (31 DNA diploid and 7 aneuploid samples). The association was statistically significant for the chromosomal regions 5p13.33-pter $(p=0.0005), 20 q 13.31-q 13.33(p=0.01)$ and $9 \mathrm{p} 21.3(p=0.00004)$. It is of note that the $20 \mathrm{q}$ gain, which extends beyond 20q13.33 up to 20qter and was commonly present among the ODFs/OPMLs $(14 / 38=37 \%)$ was only slightly associated with DNA aneuploidy $(p=0.077)$.

\section{Discussion}

The concept of field cancerization in oral cancer has been widely described and discussed [7-10] suggesting that premalignant changes may occur in any region of the oral mucosa exposed to carcinogens. According to Dakubo et al., the field cancerization represents a "process whereby cells in a particular tissue or organ are transformed, such that genetically altered but histologically normal appearing cells predate the development of neoplasia or coexist with malignant cells, irrespective of clonality" [34].

More than 60 chemicals derived from tobacco smoking that may bind and mutate a large number of genes [6] may contribute to create such an extensive oral field of cancerization. Along these concepts, a very attractive genetic progression model of oral cancer was proposed [10]. A critical step in this model, however, appears the transition from an early precursor to an expanding field with numerous aberrations, which sometimes becomes visible as leukoplakias or oral potentially malignant lesions (OPMLs) [11-15].

In recent years, the powerful technique of Comparative Genomic Hybridization (metaphase-CGH and, more lately, array-CGH) has provided a genome-wide analysis of DNA copy number aberrations (CNAs) suggesting that CNA gains and losses may result respectively in hyper- and hypo-expression of specific genes [35]. These studies, which mainly analyzed oral squamous cell carcinomas (OSCCs) and more rarely OPMLs, have identified several aberrant chromosomal loci including 1p36.3, 3q26, 5p, 7p, $8 \mathrm{q}, 9 \mathrm{p}, 11 \mathrm{q} 13,16 \mathrm{p}, 16 \mathrm{q}, 17 \mathrm{q}, 20 \mathrm{q}$ and have contributed to a better understanding of the development of oral cancer and of its clinical implications [11-15, 21-27].
Table 3 Relative number of ODFs and OPMLs with CNAgains and CNA-losses

\begin{tabular}{|c|c|c|c|c|c|}
\hline & \multicolumn{2}{|l|}{ ODFs } & \multicolumn{2}{|c|}{ OPMLs } & Fisher exact test $(p=)$ \\
\hline \multicolumn{6}{|c|}{ CNA_gains } \\
\hline absent & 12 & $(63.2 \%)$ & 9 & $(47.4 \%)$ & 0.5 \\
\hline present & 7 & $(36.8 \%)$ & 10 & $(52.6 \%)$ & \\
\hline \multicolumn{6}{|c|}{ CNA-losses } \\
\hline absent & 19 & $(100 \%)$ & 13 & $(68.4 \%)$ & 0.019 \\
\hline present & 0 & $(0 \%)$ & 6 & $(31.6 \%)$ & \\
\hline
\end{tabular}


Table 4 Detailed overview of minimal common region CNA-gains in ODFs and OPMLs

\begin{tabular}{|c|c|c|c|c|c|c|c|c|}
\hline \multirow[t]{2}{*}{ Common CNA-gains } & \multicolumn{2}{|c|}{ Position (bp) } & \multirow{2}{*}{$\begin{array}{l}\text { Segment size } \\
\mathrm{Mb}\end{array}$} & \multirow[t]{2}{*}{$\mathrm{n}^{\circ}$ of genes } & \multicolumn{2}{|c|}{ ODFs $(n=19)$} & \multicolumn{2}{|c|}{ OPMLs $(n=19)$} \\
\hline & Start & End & & & & & & \\
\hline 1p36.32-pter & 604268 & 4312064 & 3.71 & 41 & 3 & $(16 \%)$ & 3 & $(16 \%)$ \\
\hline 7p22.2-pter & 149268 & 1973885 & 1.82 & 14 & 4 & $(21 \%)$ & 6 & $(32 \%)$ \\
\hline 8q24.3-qter & 142173802 & 146250824 & 4.08 & 69 & 3 & $(16 \%)$ & 7 & $(37 \%)$ \\
\hline $11 \mathrm{p} 15.5$-pter & 186966 & 2789993 & 2.60 & 53 & 4 & $(21 \%)$ & 4 & $(21 \%)$ \\
\hline 16p13.3-pter & 36766 & 2592859 & 2.56 & 84 & 4 & $(21 \%)$ & 4 & $(21 \%)$ \\
\hline 20q13.33-qter & 59483462 & 62194881 & 2.71 & 52 & 7 & $(37 \%)$ & 7 & $(37 \%)$ \\
\hline
\end{tabular}

In the present study, we demonstrated that the vast majority of these aberrant chromosomal regions were already present in our series of OPMLs and corresponding non-dysplastic visually normal mucosa oral fields (ODFs). In particular, some specific CNAs that were present at high frequencies (between 40 and 60\%) in the d-OPMLs (for example, loss at 9p21.3 and gain at 20q13.31-q13.33) were absent or at very low frequency in all the other samples.

The additional use of high resolution DNA flow cytometry (hr DNA-FCM) carries two relevant advantages. First, it allows (with the use of the technical capability of DNA-FCM-Sorting) to identify the presence of DNA aneuploid sublines and to physically separate them from the DNA diploid components and to submit therefore a relatively pure population of epithelial aneuploid nuclei to a-CGH. Second, this combined approach made it possible to compare the DNA aberrations obtained by hr DNA-FCM and a-CGH and to eventually indicate genomic regions underlying the development of DNA aneuploid sublines.

Among the 10 different aberrant chromosomal regions that we have detected for both ODFs and OPMLs, we found that loss at $9 \mathrm{p} 21.3$ and gains at 5p13.33-pter and 20q13.31-q13.33 were associated with DNA aneuploidy $(p=0.00004 ; p=0.0005 ; p=0.01)$. Though based on a relatively small number of ODF/OPML samples $(n=38)$, these results represent a new finding, which suggests that candidate genes within these chromosomal regions may be linked with mechanisms of chromosomal instability and aneuploidy. In particular, the chromosomal loss in the region 9 p21.3 appears to be an interesting one, because it is characterized by a small size of only $2.16 \mathrm{Mb}$ and only 9 genes, because $50 \%$ of the d-OPMLs lost this region and also because it is strongly correlated with DNA aneuploidy. Clearly, only specific types of studies may identify which specific gene/s may be responsible for such an important change as DNA aneuploidization. As far as known function of genes located in this region, we recall the gene $C D K N 2 A$ (Cyclin-dependent kinase inhibitor 2A or TP16). This tumor suppressor gene, which is frequently inactivated by methylation, gene mutation and allelic deletions, was reported to play an important role in the carcinogenesis of OSCCs [36]. Also the chromosomal region 5p15.33-pter (segment size $=$ 1.9), which was similarly associated with DNA aneuploidy, is an interesting one. Within this region, we recall the hTERT gene (Telomerase reverse transcriptase), which was implicated in telomerase-mediated chromosomal instability along with cell growth and apoptosis imbalances [37, 38].

Finally, we like to cite the RTEL1 gene (Regulator of telomere elongation helicase 1) located in the 20q13.33-qter region, which was commonly present among the ODFs/ OPMLs. This gene was reported to play a crucial role in telomere maintenance, chromosomal instability, DNA repair, negative regulation of apoptosis and was found to be amplified in several human cancers [39-42].

Clearly, the identification of genes responsible for chromosomal instability and aneuploidization in the early phases of oral carcinogenesis represented by ODFs and OPMLs would be a very important task. With respect to our a-CGH data, we have also posed this question: have the ODFs and the OPMLs some chromosomal aberrations in common? The observation that some CNAs at specific chromosomal regions for the ODFs (1p36.32-pter, 7p22.2-
Table 5 Unique types of CNAs present in the d-OPMLs that were absent or at very low frequency in all the other samples

\begin{tabular}{|c|c|c|c|c|c|c|c|}
\hline \multirow[t]{2}{*}{ CNAs } & & \multicolumn{2}{|c|}{ Position (bp) } & \multirow{2}{*}{$\begin{array}{l}\text { Segment size } \\
\mathrm{Mb}\end{array}$} & \multirow[t]{2}{*}{$\mathrm{n}^{\circ}$ of genes } & \multicolumn{2}{|c|}{ d-OPMLs $(n=8)$} \\
\hline & & Start & End & & & & \\
\hline \multirow[t]{3}{*}{ Gains } & 5p15.33-pter & 75149 & 2038701 & 1.9 & 21 & 4 & $(50.0 \%)$ \\
\hline & 16q24.2-qter & 85963377 & 88690615 & 2.73 & 49 & 3 & $(37.5 \%)$ \\
\hline & 20q13.31-q13.33 & 55096989 & 59483462 & 4.39 & 30 & 5 & $(62.5 \%)$ \\
\hline Loss & $9 \mathrm{p} 21.3$ & 21114875 & 23278698 & 2.16 & 9 & 4 & $(50.0 \%)$ \\
\hline
\end{tabular}


Table 6 Loss at 9p21.3, gain at $5 \mathrm{p} 13.33$-pter and gain of 20q13.31-q13.33 were associated with DNA aneuploidy

\begin{tabular}{|c|c|c|c|c|c|}
\hline \multicolumn{3}{|l|}{ CNAs } & \multirow{3}{*}{$\begin{array}{l}\text { DNA diploid }(n=31) \\
27 \\
4\end{array}$} & \multirow{2}{*}{$\begin{array}{l}\text { DNA aneuploid }(n=7) \\
5\end{array}$} & \multirow{2}{*}{$\frac{p=(\text { Fisher test })}{0.3}$} \\
\hline \multirow[t]{18}{*}{ Gains } & 1p36.32-pter & absent & & & \\
\hline & & present & & 2 & \\
\hline & 5p13.33-pter & absent & 31 & 3 & 0.00047 \\
\hline & & present & 0 & 4 & \\
\hline & 7 p22.2-pter & absent & 24 & 4 & 0.35 \\
\hline & & present & 7 & 3 & \\
\hline & 8q24.3-qter & absent & 25 & 3 & 0.062 \\
\hline & & present & 6 & 4 & \\
\hline & $11 \mathrm{p} 15.5$-pter & absent & 24 & 6 & 1 \\
\hline & & present & 7 & 1 & \\
\hline & 16p13.3-pter & absent & 26 & 4 & 0.14 \\
\hline & & present & 5 & 3 & \\
\hline & 16q24.2-qter & absent & 28 & 4 & 0.063 \\
\hline & & present & 3 & 3 & \\
\hline & 20q13.31-q13.33 & absent & 28 & 3 & 0.013 \\
\hline & & present & 3 & 4 & \\
\hline & 20q13.33-qter & absent & 22 & 2 & 0.077 \\
\hline & & present & 9 & 5 & \\
\hline \multirow[t]{2}{*}{ Loss } & $9 \mathrm{p} 21.3$ & absent & 31 & 2 & 0.000041 \\
\hline & & present & 0 & 5 & \\
\hline
\end{tabular}

pter, 8q24.2-qter, 11p15.5-pter, 16p13.3-pter, 20q13.33qter) were also present (in almost all cases at increasing frequencies) for the OPMLs might suggest that these aberrations could have played a role in the ODF-OPML transition and that they may be clonally related. In other words, the ODFs might represent in some cases an early precursor of the OPMLs of the same patient. It is to be noticed, however, that two ODFs with CGH aberrations had 2 corresponding nd-OPMLs without aberrations. This might also imply that the origin of either ODFs or ndOPMLs may be polyclonal. Clearly, we are well aware that these chromosomal aberrant regions are quite large and might contain a large number of genes beside those eventually involved in the ODF-OPML transition.

With respect to the hr DNA-FCM data, we found that among the 19 ODFs of the present series, only one was characterized by a DNA Index value different from 1 (DI $\neq$ $1)$, i.e., by a DNA aneuploid subpopulation $(1 / 19=5.26 \%)$. On the contrary, DNA aneuploid subpopulations were detected in 6 out of 19 OPMLs (32\%). These results suggest that DNA aneuploidization is a relatively frequent early event in OPMLs and that sporadically such early aberration may already occur in ODFs within the same anatomical subsite. In no cases, however, we detected a common DNA aneuploid subline (with the same DI value) in both ODFs and corresponding OPMLs. Clearly, a much greater number of cases is needed to address this question. These data are in agreement with an independent study performed only by DNA-FCM in which we found that the percentage of DNA aneuploid ODFs and OPMLs were respectively $8.5 \%$ and $28 \%$ [20].

The absence of a DNA aneuploid component in the pure DNA diploid samples did not allow an enrichment of the epithelial component and therefore diploid stromal cells were also present with the epithelial cells. It is also to be noticed that the amount of material was not sufficient to obtain DNA diploid suspensions of cells to be marked and sorted according to epithelial specific antibodies and then to be reduced to nuclei suspensions and extracted DNA. The presence of epithelial cells (at least 50\%) in the DNA diploid samples was controlled by morphological inspection from tissue samples obtained in parallel with the ODF/OPML samples.

In conclusion, specific aberrant chromosomal regions detected by high resolution a-CGH in oral visually and histologically normal fields and in potentially malignant lesions appear to be early events of the natural history of oral cancer associated with an early onset of the field cancerization and with DNA aneuploidy. Work remains to be done to identify possible specific genes within the CNA common regions, which might potentially contribute to the ODF-OPML transition and to DNA aneuploidization. The detection of these genomic aberrations, including DNA aneuploidy, which is prone to routine analysis, may help to identify individual patients with OPMLs at high risk to develop OSCCs and indicate alternative criteria for the management of these patients [34, 43-45]. Clearly, the validation of this hypothesis requires long term prospective follow-up studies with an appropriate number of cases. 
Acknowledgements This study has been supported by Philip Morris International and "Compagnia di San Paolo-Programma Oncologia".

\section{Conflict of interest statement None declared.}

Open Access This article is distributed under the terms of the Creative Commons Attribution Noncommercial License which permits any noncommercial use, distribution, and reproduction in any medium, provided the original author(s) and source are credited.

\section{References}

1. J. Califano, P. van der Riet, W. Westra, H. Nawroz, G. Clayman, S. Piantadosi, R. Corio, D. Lee, B. Greenberg, W. Koch, D. Sidransky, Genetic progression model for head and neck cancer: implications for field cancerization. Cancer Res. 56, 2488-2492 (1996)

2. D. Hanahan, R.A. Weinberg, Hallmarks of cancer: the next generation. Cell 144, 646-674 (2011)

3. A. Martorell-Calatayud, R. Botella-Estrada, J.V. BaganSebastian, O. Sanmartin-Jimenez, C. Guillen-Barona, Oral leukoplakia: clinical, histopathologic, and molecular features and therapeutic approach. Actas Dermosifiliogr 100, 669-684 (2009)

4. "Tobacco smoking," in Monogr Eval Carcinog Risk Chem Hum (IARC 1986), pp. 35-394.

5. "Tobacco smoke and involuntary smoking," in Monogr Eval Carcinog Risks Hum(IARC 2004), pp. 1-1438.

6. E.D. Pleasance, P.J. Stephens, S. O'Meara, D.J. McBride, A. Meynert, D. Jones, M.L. Lin, D. Beare, K.W. Lau, C. Greenman, I. Varela, S. Nik-Zainal, H.R. Davies, G.R. Ordonez, L.J. Mudie, C. Latimer, S. Edkins, L. Stebbings, L. Chen, M. Jia, C. Leroy, J. Marshall, A. Menzies, A. Butler, J.W. Teague, J. Mangion, Y.A. Sun, S.F. McLaughlin, H.E. Peckham, E.F. Tsung, G.L. Costa, C. C. Lee, J.D. Minna, A. Gazdar, E. Birney, M.D. Rhodes, K.J. McKernan, M.R. Stratton, P.A. Futreal, and P.J. Campbell, "A small-cell lung cancer genome with complex signatures of tobacco exposure." Nature 463, 184-190.

7. D.P. Slaughter, H.W. Southwick, W. Smejkal, Field cancerization in oral stratified squamous epithelium; clinical implications of multicentric origin. Cancer 6, 963-968 (1953)

8. B.J. Braakhuis, M.P. Tabor, J.A. Kummer, C.R. Leemans, R.H. Brakenhoff, A genetic explanation of Slaughter's concept of field cancerization: evidence and clinical implications. Cancer Res. 63, 1727-1730 (2003)

9. M.P. Tabor, R.H. Brakenhoff, V.M. van Houten, J.A. Kummer, M. H. Snel, P.J. Snijders, G.B. Snow, C.R. Leemans, B.J. Braakhuis, Persistence of genetically altered fields in head and neck cancer patients: biological and clinical implications. Clin. Cancer Res. 7, 1523-1532 (2001)

10. B.J. Braakhuis, C.R. Leemans, R.H. Brakenhoff, A genetic progression model of oral cancer: current evidence and clinical implications. J Oral Pathol Med 33, 317-322 (2004)

11. V.M. van Houten, M.P. Tabor, M.W. van den Brekel, F. Denkers, R.G. Wishaupt, J.A. Kummer, G.B. Snow, R.H. Brakenhoff, Molecular assays for the diagnosis of minimal residual head-andneck cancer: methods, reliability, pitfalls, and solutions. Clin. Cancer Res. 6, 3803-3816 (2000)

12. C.B. Reid, G.B. Snow, R.H. Brakenhoff, B.J. Braakhuis, Biologic implications of genetic changes in head and neck squamous cell carcinogenesis. Aust. N. Z. J. Surg. 67, 410-416 (1997)

13. B.J. Braakhuis, M.P. Tabor, C.R. Leemans, I. van der Waal, G.B. Snow, R.H. Brakenhoff, Second primary tumors and field cancerization in oral and oropharyngeal cancer: molecular techniques provide new insights and definitions. Head Neck 24, 198-206 (2002)

14. S.M. Gollin, Chromosomal alterations in squamous cell carcinomas of the head and neck: window to the biology of disease. Head Neck 23, 238-253 (2001)

15. A. Forastiere, W. Koch, A. Trotti, D. Sidransky, Head and neck cancer. N. Engl. J. Med. 345, 1890-1900 (2001)

16. W.M. Lydiatt, P.E. Anderson, T. Bazzana, M. Casale, C.J. Hughes, A. G. Huvos, D.D. Lydiatt, S.P. Schantz, Molecular support for field cancerization in the head and neck. Cancer 82, 1376-1380 (1998)

17. J.F. Bremmer, B.J. Braakhuis, A. Brink, M.A. Broeckaert, J.A. Belien, G.A. Meijer, D.J. Kuik, C.R. Leemans, E. Bloemena, I. van der Waal, R.H. Brakenhoff, Comparative evaluation of genetic assays to identify oral pre-cancerous fields. J Oral Pathol Med 37, 599-606 (2008)

18. N. Voravud, D.M. Shin, J.Y. Ro, J.S. Lee, W.K. Hong, W.N. Hittelman, Increased polysomies of chromosomes 7 and 17 during head and neck multistage tumorigenesis. Cancer Res. 53, 2874$2883(1993)$

19. M. Nees, N. Homann, H. Discher, T. Andl, C. Enders, C. HeroldMende, A. Schuhmann, F.X. Bosch, Expression of mutated p53 occurs in tumor-distant epithelia of head and neck cancer patients: a possible molecular basis for the development of multiple tumors. Cancer Res. 53, 4189-4196 (1993)

20. A. Donadini, M. Maffei, A. Cavallero, M. Pentenero, D. Malacarne, E. Di Nallo, M. Truini, R. Navone, P. Mereu, M. Scala, A. Santelli, S. Gandolfo, W. Giaretti, Oral cancer genesis and progression: DNA near-diploid aneuploidization and endoreduplication by high resolution flow cytometry. Cell. Oncol. 32, 373-383 (2010)

21. S. Pathare, A.A. Schaffer, N. Beerenwinkel, M. Mahimkar, Construction of oncogenetic tree models reveals multiple pathways of oral cancer progression. Int. J. Cancer 124, 2864-2871 (2009)

22. Y. Noutomi, A. Oga, K. Uchida, M. Okafuji, M. Ita, S. Kawauchi, T. Furuya, Y. Ueyama, K. Sasaki, Comparative genomic hybridization reveals genetic progression of oral squamous cell carcinoma from dysplasia via two different tumourigenic pathways. J. Pathol. 210, 67-74 (2006)

23. E. Wolff, S. Girod, T. Liehr, U. Vorderwulbecke, J. Ries, H. Steininger, E. Gebhart, Oral squamous cell carcinomas are characterized by a rather uniform pattern of genomic imbalances detected by comparative genomic hybridisation. Oral Oncol 34, 186-190 (1998)

24. S.J. Smeets, B.J. Braakhuis, S. Abbas, P.J. Snijders, B. Ylstra, M. A. van de Wiel, G.A. Meijer, C.R. Leemans, R.H. Brakenhoff, Genome-wide DNA copy number alterations in head and neck squamous cell carcinomas with or without oncogene-expressing human papillomavirus. Oncogene 25, 2558-2564 (2006)

25. J.A. Squire, J. Bayani, C. Luk, L. Unwin, J. Tokunaga, C. MacMillan, J. Irish, D. Brown, P. Gullane, S. Kamel-Reid, Molecular cytogenetic analysis of head and neck squamous cell carcinoma: By comparative genomic hybridization, spectral karyotyping, and expression array analysis. Head Neck 24, 874-887 (2002)

26. C.J. Liu, S.C. Lin, Y.J. Chen, K.M. Chang, K.W. Chang, Arraycomparative genomic hybridization to detect genomewide changes in microdissected primary and metastatic oral squamous cell carcinomas. Mol. Carcinog. 45, 721-731 (2006)

27. A.M. Snijders, B.L. Schmidt, J. Fridlyand, N. Dekker, D. Pinkel, R.C. Jordan, D.G. Albertson, Rare amplicons implicate frequent deregulation of cell fate specification pathways in oral squamous cell carcinoma. Oncogene 24, 4232-4242 (2005)

28. W. Giaretti, A model of DNA aneuploidization and evolution in colorectal cancer. Lab Invest 71, 904-910 (1994)

29. R. Navone, M. Pentenero, I. Rostan, P. Burlo, A. Marsico, R. Broccoletti, C. Scully, S. Gandolfo, Oral potentially malignant 
lesions: first-level micro-histological diagnosis from tissue fragments sampled in liquid-based diagnostic cytology. J Oral Pathol Med 37, 358-363 (2008)

30. I. van der Waal, Potentially malignant disorders of the oral and oropharyngeal mucosa; terminology, classification and present concepts of management. Oral Oncol 45, 317-323 (2009)

31. Pathology and Genetics of Head and Neck Tumours. (International Agency for Research on Cancer (IARC), 2005).

32. F.J. Otto, "High-resolution analysis of nuclear DNA employing the fluorochrome DAPI," in Methods Cell Biol (Academic Press San Diego, 1994), pp. 211-217.

33. M.G. Ormerod, B. Tribukait, W. Giaretti, Consensus report of the task force on standardisation of DNA flow cytometry in clinical pathology. DNA Flow Cytometry Task Force of the European Society for Analytical Cellular Pathology. Anal. Cell. Pathol. 17, 103-110 (1998)

34. G.D. Dakubo, J.P. Jakupciak, M.A. Birch-Machin, R.L. Parr, Clinical implications and utility of field cancerization. Cancer Cell Int 7, 2 (2007)

35. D.G. Albertson, C. Collins, F. McCormick, J.W. Gray, Chromosome aberrations in solid tumors. Nat. Genet. 34, 369-376 (2003)

36. S. Ohta, H. Uemura, Y. Matsui, H. Ishiguro, K. Fujinami, K. Kondo, H. Miyamoto, T. Yazawa, K. Danenberg, P.V. Danenberg, I. Tohnai, Y. Kubota, Alterations of p16 and p14ARF genes and their 9p21 locus in oral squamous cell carcinoma. Oral Surg Oral Med Oral Pathol Oral Radiol Endod 107, 81-91 (2009)

37. D. Del Bufalo, A. Rizzo, D. Trisciuoglio, G. Cardinali, M.R. Torrisi, U. Zangemeister-Wittke, G. Zupi, A. Biroccio, Involvement of hTERT in apoptosis induced by interference with Bcl-2 expression and function. Cell Death Differ 12, 1429-1438 (2005)

38. Y.H. Sung, Y.S. Choi, C. Cheong, H.W. Lee, The pleiotropy of telomerase against cell death. Mol Cells 19, 303-309 (2005)
39. G. Pannone, S. De Maria, R. Zamparese, S. Metafora, R. Serpico, F. Morelli, C. Rubini, E. Farina, M. Carteni, S. Staibano, G. De Rosa, L. Lo Muzio, P. Bufo, Prognostic value of human telomerase reverse transcriptase gene expression in oral carcinogenesis. Int. J. Oncol. 30, 1349-1357 (2007)

40. E.J. Uringa, J.L. Youds, K. Lisaingo, P.M. Lansdorp, S.J. Boulton, RTEL1: an essential helicase for telomere maintenance and the regulation of homologous recombination. Nucleic Acids Res. 39, 1647-1655 (2011)

41. L.J. Barber, J.L. Youds, J.D. Ward, M.J. McIlwraith, N.J. O’Neil, M.I. Petalcorin, J.S. Martin, S.J. Collis, S.B. Cantor, M. Auclair, H. Tissenbaum, S.C. West, A.M. Rose, S.J. Boulton, RTEL1 maintains genomic stability by suppressing homologous recombination. Cell 135, 261-271 (2008)

42. G. Xiong, H. Guo, X. Ge, X. Xu, X. Yang, K. Yang, Y. Jiang, and Y. Bai, "Decoy receptor 3 expression in esophageal squamous cell carcinoma: correlation with tumour invasion and metastasis," Biomarkers 16, 155-160.

43. M. Pentenero, W. Giaretti, R. Navone, A. Demurtas, I. Rostan, G. Bertolusso, R. Broccoletti, P.G. Arduino, D. Malacarne, S. Gandolfo, DNA aneuploidy and dysplasia in oral potentially malignant disorders: association with cigarette smoking and site. Oral Oncol 45, 887-890 (2009)

44. G. Lodi, A. Sardella, C. Bez, F. Demarosi, and A. Carrassi, "Interventions for treating oral leukoplakia," Cochrane Database Syst Rev, CD001829 (2006).

45. M. Brennan, C.A. Migliorati, P.B. Lockhart, D. Wray, I. Al-Hashimi, T. Axell, A.J. Bruce, W. Carpenter, E. Eisenberg, J.B. Epstein, P. Holmstrup, M. Jontell, R. Nair, H. Sasser, M. Schifter, B. Silverman, K. Thongprasom, M. Thornhill, S. Warnakulasuriya, I. van der Waal, Management of oral epithelial dysplasia: a review. Oral Surg Oral Med Oral Pathol Oral Radiol Endod 103(S19), e11-12 (2007) 